\title{
Influence of the Concentration of Glucose and Galactose on the Physiology of Saccharomyces cerevisiae in Continuous Culture
}

\author{
By C. M. BROWN AND B. JOHNSON \\ Department of Microbiology, University of Newcastle upon Tyne
}

(Accepted for publication 21 October 1970)

\section{SUMMARY}

The effect of increasing concentrations of glucose and galactose on the physiology and composition of Saccharomyces cerevisiae was studied in continuous culture. Glucose, at concentrations ranging from I to $50 \mathrm{~g} . / 1$. was degraded predominantly by aerobic fermentation. Galactose catabolism was mainly aerobic at concentrations up to $5 \mathrm{~g}$./1. but became increasingly fermentative at higher sugar concentrations. The fatty-acid content varied with the type of metabolism. Thus at low concentrations of sugar, fatty acids accounted for $8 \%$ dry wt but about $5 \%$ dry wt at high sugar concentrations. High sugar concentrations may be associated with the repression of mitochondrial structures.

The size of the amino acid pool was a function of the availability of ammonia in the medium. Such 'pools' contained appreciable amounts of arginine when $\mathrm{NH}_{4}{ }^{+}$was in excess, whereas in the absence of $\mathrm{NH}_{4}{ }^{+}$from the culture filtrate only trace amounts of arginine were detected. The content of glutamic dehydrogenase in the yeast varied directly with the availability of ammonia and the size of the amino acid pool.

\section{INTRODUCTION}

Saccharomyces cerevisiae, grown in the presence of glucose or fructose as the source of carbon and energy, degraded the sugar by aerobic fermentation. When grown on galactose or mannose, degradation proceeded simultaneously by respiration as well as by fermentation (De Deken, 1966). Such a repression of respiratory enzymes by high fermentation rates is known as the 'Crabtree effect'. The concentration of glucose in the medium is of prime importance. Thus Slonimski (I956) showed that up to $6 \times 10^{-3} \mathrm{M}$-glucose stimulated the rate of respiratory adaptation in anaerobically grown $S$. cerevisiae. At higher concentrations the rate of adaptation decreased while that of fermentation increased. Similarly, Polakis, Bartley \& Meek (I965) showed that when grown in the presence of low concentrations of glucose $(0.09 \%)$ or galactose $(0.9 \%) S$. carlsbergensis synthesized respiratory enzymes and possessed functional mitochondria. In contrast, cells grown in the presence of $0.9 \%$ glucose did not contain recognizable mitochondria and only low levels of respiratory enzymes were detected. The effects of high concentrations of galactose were not determined.

Increasing the glucose concentration from $0.6 \%$ to $20 \%$ in cultures of Candida parapsilosis increased the concentrations of several enzymes; in particular the contents of glyceraldehyde phosphate dehydrogenase, phosphoglycerate kinase and pyruvic decarboxylase increased four- to tenfold (Hommes, I966). Babij, Moss \& Ralph (I969) showed that increasing the glucose concentration in cultures of $C$. utilis from $0 . \mathrm{I} \%$ to 
$4.5 \%$ also increased the total fatty-acid content of this yeast from $2 \%$ to $10 \%$ dry weight. The size of the amino acid pool in Saccharomyces cerevisiae is dependent on the nature of the limiting substrate in chemostat cultures. In yeasts obtained from glucose-limited cultures this pool is almost three times that from $\mathrm{NH}_{4}^{+}$limited cultures (D. W. Tempest, J. L. Meers \& C. M. Brown, unpublished). This paper presents the results of a study of the effects of increasing concentrations of glucose and galactose on the composition and physiology of $S$. cerevisiae in chemostat cultures.

\section{METHODS}

Saccharomyces cerevisiae (NCYC712, described by Brown \& Hough, 1965) was maintained by monthly subculture on yeast extract $(\mathrm{I} \%, \mathrm{w} / \mathrm{v})$, peptone $(2 \%, \mathrm{w} / \mathrm{v})$, glucose, $(2 \%, \mathrm{w} / \mathrm{v})$ agar.

Growth conditions. Organisms were grown in 0.51 . Porton-type chemostats at a dilution rate of $0.1 \mathrm{~h}^{-1}$ at $25^{\circ}$ and at a pH of 4.5 , as described by Brown \& Rose (1969 a). The medium employed was: $\mathrm{KH}_{2} \mathrm{PO}_{4}, \mathrm{I} 5 \mathrm{mM} ; \mathrm{MgSO}_{4}, 4 \mathrm{mM} ; \mathrm{CaCl}_{2}, \mathrm{I} \mathrm{mM}$; inositol, $\mathrm{I} \cdot \mathrm{I} \times \mathrm{IO}^{-4} \mathrm{M}$; pyridoxine $\mathrm{HCl}, \mathrm{I} \cdot 0 \times \mathrm{IO}^{-5} \mathrm{M}$; calcium pantothenate, $\mathrm{I} \cdot \mathrm{O} \times$ $\mathrm{IO}^{-5} \mathrm{M}$; thiamine $\mathrm{HCl}, \mathrm{I} \cdot 2 \times \mathrm{IO}^{-6} \mathrm{M}$; biotin $4 \times \mathrm{IO}^{-9} \mathrm{M}$; with trace amounts of $\mathrm{Zn}^{2+}$, $\mathrm{MoO}_{4}^{2-}, \mathrm{Cu}^{2+}, \mathrm{Fe}^{3+}$ and $\mathrm{Mn}^{2+}$. The nitrogen source was $\left(\mathrm{NH}_{4}\right)_{2} \mathrm{SO}_{4} 2 \mathrm{mM}$, and glucose and galactose were added as required. The galactose used (British Drug Houses, Poole, Dorset) contained up to $2 \mathrm{mg}$./g. glucose. Phosphate-limited media contained $\mathrm{KH}_{2} \mathrm{PO}_{4}, 0.25 \mathrm{mM} ;\left(\mathrm{NH}_{4}\right)_{2} \mathrm{SO}_{4} ;$ IO $\mathrm{mM} ; \mathrm{KCl}, \mathrm{I} 4 \mathrm{mM}$ and glucose at Io g./l.

Analytical procedures. Samples were taken directly from chemostat cultures and harvested immediately. Yeast concentration and the contents of keto acid, ethanol, glucose and galactose in the culture filtrates were determined by the methods of Brown \& Rose (1969a). Ammonia in culture filtrates and amino acid pool samples were determined by the method of Fawcett \& Scott (1960). The rates of oxygen uptake of yeast washed in $0.0 \mathrm{I}$ M-phosphate buffer ( $\mathrm{pH} \mathrm{6.5)}$ were determined by conventional manometric methods. Amino acid pools from yeast washed twice in water at room temperature were extracted with boiling water by the method of Dawson (1965) and assayed by the ninhydrin procedure of Harris \& Parsons (1958). These 'pools', which contained low concentrations of ammonia, were qualitatively analysed on paper and thin-layer chromatograms as described by Brown \& Rose $(1969 b)$.

Duplicate samples of culture (containing about roo mg. dry wt cells) were harvested by centrifuging at $5000 \mathrm{~g}$ for $5 \mathrm{~min}$. and then analysed for fatty acids in the following way. The yeasts were washed twice in ice-cold Io mM-phosphate buffer $(\mathrm{pH} 7 \cdot 0)$ and suspended in $10 \mathrm{ml}$. of a mixture of chloroform and methanol $(2: \mathrm{I}, \mathrm{v} / \mathrm{v})$. To one suspension was added a known amount of myristic acid $\left(\mathrm{C}_{14}{ }^{\circ} \mathrm{O}\right)$ as an internal standard. These suspensions were transferred to $50 \mathrm{ml}$. stoppered flasks containing $10 \mathrm{~g}$. of glass beads (I mm. diam.; Jencons, Hemel Hempstead, Hertfordshire), 5 ml. chloroform/methanol was used for washing. The flasks were then flushed with nitrogen, stoppered, shaken for $\mathrm{I} h$. at room temperature on a wrist-action shaker (Griffin \& George, London) and left overnight. The turbid supernatant fluid was then decanted from the beads, which were washed twice with $5 \mathrm{ml}$. chloroform/methanol. The washings were added to the decanted extract and the mixture centrifuged at $3000 \mathrm{~g}$ at room temperature for $5 \mathrm{~min}$. The clear supernatant fluid was then removed and 
evaporated to dryness at $40^{\circ}$ on a Buckler evapomix (Buckler Instruments Inc., Fort Worth, New Jersey, U.S.A.). The residue was taken up in $5 \mathrm{ml}$. petroleum spirit (40 to $60^{\circ}$ ). The solution was removed and again dried. This step was repeated. The material remaining was taken up in $5 \mathrm{ml}$. of petroleum spirit and this solution transferred to a $50 \mathrm{ml}$. flask of the design suggested by Kates (1964), and the solvent removed in a stream of nitrogen. The production of methyl esters, their chromatography and quantitative assessment were as described by Brown \& Rose (1969b).

To prepare enzyme extracts, freshly harvested yeast (about $200 \mathrm{mg}$. dry wt) was washed twice with $20 \mathrm{ml}$. of phosphate buffer ( $10 \mathrm{mM}, \mathrm{pH} 7.0$ ) containing I mMmercaptoethanol and $0.25 \mathrm{M}$-sucrose, and then suspended in $7 \mathrm{ml}$. buffer. This suspension was transferred to chilled vessels containing $5 \mathrm{~g}$. of $\mathrm{I} \cdot 0 \mathrm{~mm}$. diam. glass beads, shaken at maximum amplitude in a Mickle disintegrator for $30 \mathrm{~min}$. and then centrifuged at $1500 \mathrm{~g}$ for $10 \mathrm{~min}$., when most of the cell walls and debris sedimented amongst the beads. The supernatant fluid was removed with a pipette, centrifuged at $75,000 \mathrm{~g}$ for $30 \mathrm{~min}$. and the clear supernatant retained for enzyme analysis. The activities of glutamic dehydrogenase (NADP), pyruvic decarboxylase and alcohol dehydrogenase were measured by recording the rates of oxidation or reduction of coenzyme at $340 \mathrm{~nm}$. in a Unicam SP 500 series II spectrophotometer equipped with an SP $22 \mathrm{log}$ / linear recorder (Pye/Unicam, Cambridge). The test solutions were: for glutamic dehydrogenase, $6.7 \mathrm{~mm} 2$ oxo-glutarate, $2 \mathrm{~mm}$ cysteine, $67 \mathrm{~mm} \mathrm{NH}_{3}, 5 \mathrm{~mm}$ EDTA, $0.23 \mathrm{~mm}$ NADPH, and Io mM-phosphate buffer ( $\mathrm{pH} \mathrm{6.5)} \mathrm{to} \mathrm{a} \mathrm{final} \mathrm{volume} \mathrm{of} 3 \mathrm{ml}$.; for pyruvic decarboxylase, $3.3 \mathrm{mM} \mathrm{Mg}^{2+}, 3.3 \mathrm{~mm}$ cysteine, I.67 mM thiamine pyrophosphate, $20 \mu \mathrm{g}$ alcohol dehydrogenase, $0.23 \mathrm{~mm} \mathrm{NADH}$, and Io mM-phosphate buffer (pH 6.5) to $3 \mathrm{ml}$; for alcohol dehydrogenase, $25 \mathrm{~mm}$ ethanol, $0.23 \mathrm{~mm}$ NAD, and $10 \mathrm{~mm}$ phosphate buffer ( $\mathrm{pH} \mathrm{6.5)} \mathrm{containing} 20 \mathrm{~mm}$ semicarboxide hydrochloride to a final volume of $3 \mathrm{ml}$. The protein content of enzyme extracts was determined by the method of Lowry, Rosebrough, Farr \& Randall (I95I) with bovine serum albumin as standard.

\section{RESULTS}

Effect of sugar concentration on growth

The concentration of glucose and galactose employed and their effects on yeast concentration and components of the culture filtrate are shown in Table $I$. When the initial concentration of either sugar in the medium was low, only trace amounts could be detected in the culture filtrates, but as the initial concentrations were increased there was a concomitant increase in the residual amounts. Conversely the $\mathrm{NH}_{4}^{+}$concentrations present in the culture filtrates were high at low concentrations of sugar and virtually absent at high concentrations. Thus the cultures were probably carbonlimited at low concentrations of sugar and $\mathrm{NH}_{4}^{+}$- limited at high sugar concentrations. This was reflected in the changes in amounts of ethanol and keto acid (only pyruvate was detected) in the culture filtrates. The production of ethanol $/ \mathrm{mg}$. yeast increased steadily as the concentration of glucose in the medium increased to Io g./l., above which the rate of increase was slower. Production of ethanol/mg. yeast was less in galactose-grown cultures, little being produced up to $2 \mathrm{~g}$./1. galactose, but appreciable amounts were produced at higher sugar concentrations. With glucose at I g./l. keto acid production was high (over I $\mathrm{mg} . / \mathrm{mg}$. organisms) and ethanol production low ( $0.5 \mathrm{mg} . / \mathrm{mg}$.) compared with that of other glucose-grown cultures. 
The yields of yeast relative to the sugar utilized are listed in Table I. With the exception of cultures grown with I g./l. glucose, cultures with glucose as carbon source had a uniformly low yield which was consistent with a fermentative degradation of that sugar. In contrast, the yield of yeast grown in galactose medium varied inversely to the concentration of galactose in the medium, reflecting a more fermentative utilization of galactose with increasing concentration of that sugar in the medium. These results suggested that high concentrations of galactose might in fact be repressing the respiratory degradation of the sugar. This notion was tested by comparing in the Warburg apparatus the respiratory activity of yeasts, grown at low and high concen-

Table I. Effect of sugar concentration on cell yield and culture filtrate components

\begin{tabular}{|c|c|c|c|c|c|c|c|}
\hline \multirow{3}{*}{$\begin{array}{c}\text { Sugar } \\
\text { concentra- } \\
\text { tion } \\
(\text { g. } / 1 .)\end{array}$} & \multirow{3}{*}{$\begin{array}{c}\text { Cell } \\
\text { concentra- } \\
\text { tion } \\
(\mathrm{mg} . / \mathrm{ml} .)\end{array}$} & \multirow{3}{*}{$\begin{array}{c}\text { Yield } \\
\text { (mg. } \\
\text { dry wt/mg. } \\
\text { sugar } \\
\text { utilized) }\end{array}$} & \multicolumn{5}{|c|}{ Culture filtrate } \\
\hline & & & \multicolumn{2}{|c|}{ Ethanol } & \multicolumn{2}{|c|}{ Keto acid } & \multirow[t]{2}{*}{$\begin{array}{c}\mathrm{NH}_{4}^{+} \\
(\mu \mathrm{g} . / \mathrm{ml} .)\end{array}$} \\
\hline & & & $\mu \mathrm{g} . / \mathrm{ml}$. & $\begin{array}{c}\mu \mathrm{g} . / \mathrm{mg} . \\
\text { dry wt }\end{array}$ & $\mu \mathrm{g} . / \mathrm{ml}$. & $\begin{array}{l}\mu \mathrm{g} . / \mathrm{mg} . \\
\text { dry wt }\end{array}$ & \\
\hline \multicolumn{8}{|c|}{ Glucose as carbon source } \\
\hline $1 \cdot 0$ & 0.05 & 0.05 & 25 & 500 & 54 & 1080 & 45 \\
\hline $2 \cdot 0$ & $0 \cdot 18$ & 0.12 & 136 & 960 & 34 & I89 & 27 \\
\hline $5 \cdot 0$ & 0.44 & 0.13 & 590 & 1345 & 47 & 107 & I \\
\hline $10 \cdot 0$ & 0.78 & 0.14 & 1440 & I 850 & 73 & 94 & $\mathbf{I}$ \\
\hline $50 \cdot 0$ & $I \cdot I I$ & 0.12 & 1800 & 2120 & 216 & 105 & 0.5 \\
\hline \multicolumn{8}{|c|}{ Galactose as carbon source } \\
\hline$I \cdot O$ & 0.34 & 0.38 & 9 & 26 & $4 \mathrm{I}$ & I 2 I & 27 \\
\hline $2 \cdot 0$ & 0.49 & 0.33 & 14 & 29 & 43 & 88 & 6 \\
\hline $5 \cdot 0$ & 0.62 & 0.22 & 169 & 273 & 61 & 97 & 4 \\
\hline $10 \cdot 0$ & 0.83 & 0.17 & 584 & 704 & 85 & 103 & 3 \\
\hline $50 \cdot 0$ & 0.87 & 0.10 & 1086 & 1250 & IIO & 126 & I \\
\hline
\end{tabular}

Table 2. Effect of sugar concentration on the oxidative capacity of Saccharomyces cerevisiae

\begin{tabular}{|c|c|c|c|c|}
\hline \multirow[b]{3}{*}{$Q_{\mathrm{o}_{2}}(\mu 1 . / \mathrm{mg} . / \mathrm{h})}$. & \multicolumn{4}{|c|}{ Sugar concentration in culture medium } \\
\hline & \multicolumn{2}{|c|}{$\begin{array}{c}\text { Glucose } \\
\text { (g./l.) }\end{array}$} & \multicolumn{2}{|c|}{$\begin{array}{c}\text { Galactose } \\
\text { (g./l.) }\end{array}$} \\
\hline & $2 \cdot 0$ & $50 \cdot 0$ & $1 \cdot 0$ & $50 \cdot 0$ \\
\hline Endogenous & $7 \cdot 0$ & $9 \cdot 3$ & $4 \cdot 3$ & I $2 \cdot 6$ \\
\hline Glucose & $65 \cdot 5$ & $22 \cdot 6$ & $60 \cdot 0$ & $22 \cdot 2$ \\
\hline Galactose & $8 \cdot 7$ & $11 \cdot 7$ & $19 \cdot 0$ & 25.6 \\
\hline
\end{tabular}

trations of sugar. The results obtained (Table 2) demonstrate that at $50 \mathrm{~g}$./l. both glucose and galactose repressed the oxidation of glucose to the same extent. They also show that yeasts grown on glucose lacked the ability to oxidize galactose and that this ability of galactose-grown cells was not affected appreciably by the concentration of galactose in the growth medium.

Over the range of sugar concentration employed the cellular concentrations of protein, carbohydrate and RNA did not vary to any marked extent. 


\section{Effect of sugar concentration on fatty-acid composition}

Gas chromatography of the methyl esters of fatty acids revealed the major components to be palmitic ( $\mathrm{CI6} \cdot 0)$, palmitoleic (CI6.I) and oleic acids ( $\mathrm{CI} 8 \cdot \mathrm{I})$, with smaller amounts of myristic $\left(\mathrm{Cr}_{14} \cdot 0\right)$ and stearic $(\mathrm{Cr} 8 \cdot 0)$ acids and traces of components corresponding to $\mathrm{CI}_{4} \cdot \mathrm{I}_{1} \mathrm{C} \mathrm{C}^{\circ} \cdot 0$ and $\mathrm{C} 8 \cdot 0$. The inclusion of a myristic acid standard in the samples enabled the amounts of individual and total components to be expressed as $\mu \mathrm{g}$. fatty acid/mg. dry weight of yeast (Table 3). Unsaturated fatty acids predominated, with palmitoleic acid consistently accounting for about $50 \%$ total. Because of the low yeast concentration produced in cultures containing glucose at I g./l. it was not possible to obtain a reproducible estimate of fatty acids for those

Table 3. Effect of sugar concentration on fatty-acid content of Saccharomyces cerevisiae

\begin{tabular}{|c|c|c|c|c|c|c|c|c|c|}
\hline \multirow{3}{*}{$\begin{array}{c}\text { Sugar } \\
\text { concentra- } \\
\text { tion } \\
\text { (g./l.) }\end{array}$} & & \multicolumn{2}{|c|}{$\mathrm{C}_{14}, \mathrm{C}_{16}, \mathrm{C}_{18}$} \\
\hline & \multicolumn{7}{|c|}{ Fatty acid ( $\mu \mathrm{g} . / \mathrm{mg}$. dry wt yeast) } & \multirow{2}{*}{$\begin{array}{c}\text { Total } \\
\text { saturated }\end{array}$} & \multirow{2}{*}{$\begin{array}{l}\text { Total un- } \\
\text { saturated }\end{array}$} \\
\hline & $14 \%$ & I4.I & $16 \cdot 0$ & I6· I & $18 \cdot 0$ & I $8 \cdot I$ & Total & & \\
\hline \multicolumn{10}{|c|}{ Glucose as carbon source } \\
\hline $2 \cdot 0$ & $\mathrm{I} \cdot 7$ & $\mathbf{I} \cdot \mathbf{I}$ & $15 \cdot 8$ & $45 \cdot 3$ & $1 \cdot 3$ & $16 \cdot 9$ & $82 \cdot 0$ & $17 \cdot 5$ & $62 \cdot 3$ \\
\hline $5 \cdot 0$ & $I \cdot 2$ & 0.3 & $10 \cdot 7$ & $26 \cdot 3$ & $\mathrm{I} \cdot 8$ & $9 \cdot 4$ & $5 \mathrm{r} \cdot 3$ & 13.7 & $36 \cdot 3$ \\
\hline $10 \cdot 0$ & 0.6 & 0.3 & $8 \cdot 9$ & 23.4 & $2 \cdot 3$ & $11 \cdot 5$ & $47 \cdot 5$ & II $\cdot 8$ & $35 \cdot 2$ \\
\hline $50 \cdot 0$ & $\mathbf{I} \cdot \mathbf{I}$ & 0.0 & $10 \cdot 2$ & $28 \cdot 8$ & $2 \cdot 7$ & I3.3 & $56 \cdot 7$ & $14 \cdot 0$ & $42 \cdot I$ \\
\hline \multicolumn{10}{|c|}{ Galactose as carbon source } \\
\hline I.O & I.5 & 0.2 & $10 \cdot 5$ & $45 \cdot 4$ & $1 \cdot 5$ & $17 \cdot 6$ & $77 \cdot 3$ & 13.5 & $62 \cdot 2$ \\
\hline $2 \cdot 0$ & I. 5 & 0.7 & 10.2 & $45 \cdot 7$ & $1 \cdot 8$ & $18 \cdot 0$ & $79^{\circ} 0$ & 13.5 & $62 \cdot 4$ \\
\hline $5 \cdot 0$ & 0.9 & 0.5 & 13.7 & $38 \cdot 2$ & $5 \cdot 0$ & $18 \cdot 9$ & $77 \cdot 4$ & 19.6 & 57.6 \\
\hline $10 \cdot 0$ & 0.4 & 0.0 & 10.5 & $30 \cdot 0$ & $3 \cdot 3$ & $17 \cdot 1$ & $62 \cdot 0$ & 14.2 & $47 \cdot I$ \\
\hline $50 \cdot 0$ & 0.6 & 0.0 & 6.5 & $22 \cdot 2$ & $1 \cdot 8$ & $12 \cdot 3$ & $43 \cdot 7$ & $8 \cdot 9$ & 34.5 \\
\hline
\end{tabular}

cells. Cultures with glucose at 2 g./1. or galactose at $\mathrm{r}, 2$ and $5 \mathrm{~g} . / 1$. contained very similar concentrations of individual and total fatty acids. In these cells fatty acids accounted for about $8 \%$ dry wt. At concentrations of glucose from $5 \mathrm{~g} . / 1$. and above and galactose from Io g./l. and above, the total fatty-acid contents decreased. Palmitoleic acid decreased most with a corresponding decrease in the total amounts of unsaturated fatty acids. The percentage composition of these fatty acids remained constant, however, even though the total fatty-acid concentrations were reduced by $40 \%$ to $50 \%$. Preliminary results obtained by chromatography of lipid fractions on silicic acid impregnated paper (Marinetti, 1962) indicated that changes in fatty-acid composition were closely followed by changes in some phospholipid components. In particular, cardiolipin was present in significant amounts in glucose-limited yeast, but in only trace amounts in yeasts grown at high concentrations of glucose: phosphatidyl ethanolamine and phosphatidyl serine showed similar though smaller changes. The total amounts of neutral lipids (glycerides, sterols and sterol esters) appeared to remain constant throughout. 
Effect of sugar concentration on the amino acid pool and the content of glutamic dehydrogenase

The sizes of the amino acid pools of these cultures, corrected for $\mathrm{NH}_{4}^{+}$content, are shown in Table 4. The 'pool' size from both glucose and galactose-grown cells decreased as the sugar concentration was increased and the nitrogen supply of the medium became limiting. The amino acid pools of this organism contain only a limited range of components (Brown, 1970; Tempest, Meers \& Brown, unpublished), glutamic acid, alanine and aspartic acid being prominent with smaller amounts of leucine, valine, lysine and arginine. By chromatography on paper and thin layers of cellulose variations in 'pool' size were shown to involve all the components listed above. The amounts of lysine and arginine showed the largest changes, these compounds being present only in trace amounts in 'pools' obtained from yeast grown at high sugar

Table 4. Effect of sugar concentration on the size of the amino acid pool and the content of glutamic dehydrogenase

\begin{tabular}{|c|c|c|c|c|}
\hline \multirow[b]{2}{*}{$\begin{array}{c}\text { Sugar } \\
\text { concentration } \\
\text { (g./l.) }\end{array}$} & \multicolumn{2}{|c|}{ Glucose } & \multicolumn{2}{|c|}{ Galactose } \\
\hline & $\begin{array}{l}\text { Amino } \\
\text { acid } \\
\text { pool size } \\
(\mu \mathrm{g} . / \mathrm{mg} .)\end{array}$ & $\begin{array}{c}\text { Glutamic } \\
\text { dehydrogenase } \\
\text { (n-mole/mg. } \\
\text { protein/min.) }\end{array}$ & $\begin{array}{l}\text { Amino } \\
\text { acid } \\
\text { pool size } \\
(\mu \mathrm{g} . / \mathrm{mg} .)\end{array}$ & $\begin{array}{c}\text { Glutamic } \\
\text { dehydrogenase } \\
\text { (n-mole/mg. } \\
\text { protein/min.) }\end{array}$ \\
\hline $1 \cdot 0$ & $14 \cdot 8$ & 620 & $6 \cdot 5$ & I 100 \\
\hline 2.0 & I I $\cdot 3$ & I 140 & $5 \cdot 3$ & 1005 \\
\hline $5 \cdot 0$ & $7 \cdot 6$ & I 850 & $4 \cdot 1$ & 1670 \\
\hline 10.0 & $3 \cdot 6$ & 1730 & I.9 & I 895 \\
\hline 50.0 & 2.5 & 2390 & $1 \cdot 9$ & 2385 \\
\hline
\end{tabular}

concentrations. The glutamic dehydrogenase (EC I.4.I.3), designated GDH, specific for NADP, has a purely biosynthetic role in metabolism and is therefore of prime importance to organisms growing on $\mathrm{NH}_{4}^{+}$as sole source of nitrogen. The GDH content of both glucose and galactose-grown cells increased as the concentration of sugar was increased (Table 4). Thus the synthesis of GDH was controlled either by the concentration of sugar, the concentration of $\mathrm{NH}_{4}^{+}$remaining in the culture filtrate, or the size of the amino acid pool. To distinguish between these possibilities a phosphate-limited culture was employed which enabled both glucose and $\mathrm{NH}_{4}^{+}$to be present in excess. In this culture the pool size was $9 \cdot 7 \mu \mathrm{g} . / \mathrm{mg}$. while the GDH content was the lowest recorded at $465 \mathrm{n}-\mathrm{mole} / \mathrm{mg}$. protein/min. Thus media with an excess of both $\mathrm{NH}_{4}^{+}$and glucose produce cells with a large amino acid pool and a substantially lowered content of GDH.

Effect of sugar concentration on the content of pyruvic decarboxylase and alcohol dehydrogenase

Pyruvic decarboxylase (EC 4.I.I.I) and alcohol dehydrogenase (EC I.I.I.I), hereafter abbreviated as $\mathrm{PD}$ and $\mathrm{ADH}$ respectively, are important to yeast degrading a sugar fermentatively in that they are responsible for the conversion of pyruvic acid to ethanol. These reactions also result in the oxidation of $\mathrm{NADH}$, and the main function of this pathway may be to act as an 'electron sink' when oxidation of pyruvate is restricted. The intracellular contents of PD and ADH were of interest in these experi- 
ments because of the increased fermentation induced by high concentrations of sugar. In cultures grown on glucose the contents of both PD and ADH were low at I g. glucose/l. but increased with increasing glucose concentration until a plateau value was reached with Io g./l. (Table 5). In contrast, the contents of these enzymes were independent of sugar concentration in galactose-grown yeasts.

Table 5. Effect of sugar concentration on the content of pyruvic decarboxylase and alcohol dehydrogenase in Saccharomyces cerevisiae

Sugar
concentratio
(g. $/ 1$.
$\mathrm{I} \cdot 0$
$2 \cdot 0$
$5 \cdot 0$
$10 \cdot 0$
$50 \cdot 0$

\begin{tabular}{|c|c|c|c|}
\hline \multicolumn{2}{|c|}{ Glucose } & \multicolumn{2}{|c|}{ Galactose } \\
\hline PD* & $\mathrm{ADH}^{*}$ & PD* $^{*}$ & $\mathrm{ADH}^{*}$ \\
\hline $\begin{array}{r}45 \\
\mathrm{I} 25\end{array}$ & $\begin{array}{l}54 \\
56\end{array}$ & $\begin{array}{l}208 \\
262\end{array}$ & $\begin{array}{l}253 \\
222\end{array}$ \\
\hline 147 & I 29 & 180 & 206 \\
\hline 260 & I94 & 197 & I94 \\
\hline 271 & 198 & 181 & 202 \\
\hline
\end{tabular}

\section{DISCUSSION}

The results reported are in agreement with those of Slonimski (1956) and Polakis et al. (1965) in that even at a glucose concentration as low as I g./l. oxidative metabolism was not apparent. The very low yield of yeast at this concentration of glucose may have been due to the fact that this glucose concentration, while sufficiently high to prevent the oxidative utilization of the sugar, was apparently too low to completely derepress the synthesis of the 'electron sink' enzymes (PD, ADH) which convert pyruvate to ethanol. This is evident in the low levels of PD and ADH found together with the very high production of pyruvate by such yeasts. Thus such yeasts were at least in part devoid of a mechanism for oxidizing NADH (produced by glycolysis), which in turn would decrease their metabolic efficiency. In medium initially containing $2 \mathrm{~g}$./l. glucose the cultures had a capacity for glucose oxidation (Table 3), a capacity which was lost at higher sugar concentrations. Relating this observation to the fatty-acid composition, it is possible that the $8 \%$ (dry wt) fatty acids found at $2 \mathrm{~g}$. glucose $/ 1$. and $\mathrm{I}, 2$ and $5 \mathrm{~g}$. galactose $/ 1$. may have been a reflexion of the presence of mitochondrial lipids. At higher concentrations of glucose and galactose where the oxidative utilization of both sugars was measurably lower, the fatty-acid concentrations of these yeasts were similarly reduced. It is significant that the cell lipids most involved in this alteration were phospholipids and in particular cardiolipin, which is a characteristic component of mitochondrial lipids (Bartley, I964; Paltauf \& Schatz, 1969). Criddle \& Schatz (1969) also showed that high concentrations of glucose can bring about such changes. They reported that growth in the presence of $10 \%$ glucose reduced the concentration of mitochondrial protein to $3 \%$ of the total as compared with II \% for cells grown in the presence of $0.8 \%$ glucose, and they concluded that glucose represses the synthesis of the inner membrane of mitochondria. It is also apparent from the present work that only at concentrations of $5 \mathrm{~g}$./l. and less was galactose a substrate which was utilized predominantly by oxidative mechanisms. Indeed, at higher concentrations the utilization of galactose became almost indistinguishable from that of glucose, with low yield values being obtained 
together with a high production of ethanol. The results obtained in the experiments described above differ from those of Babij et al. (1969) with Candida utilis. Candida utilis is an obligatory aerobic organism with little fermentative metabolism and, as was shown by De Deken (1966), does not show a positive Crabtree effect. Thus in the presence of high concentrations of sugar the metabolism of this organism remains oxidative and the 'depot fat' which accumulates as fat droplets under these conditions is possibly a reflexion of an abundance of energy and perhaps acyl-coenzyme A derivatives for biosynthesis.

The amino acid pool of this strain of Saccharomyces cerevisiae was dependent upon the availability of both $\mathrm{NH}_{4}^{+}$and carbon skeletons when growing in a defined medium. Thus when both $\mathrm{NH}_{4}^{+}$and glucose were in excess the pool was largest. It fell to a level of about $2 \mu \mathrm{g}$. nitrogen $/ \mathrm{mg}$. yeast when $\mathrm{NH}_{4}^{+}$limited growth. It is consistent with these observations that the amino acids which varied most were those with more than one nitrogen atom (arginine, lysine). Similar results were recently obtained by Middelhoven (1970), who grew $S$. cerevisiae in a defined medium containing $\left(\mathrm{NH}_{4}\right)_{2} \mathrm{SO}_{4}$ as sole source of nitrogen and then starved these cells by shaking in nitrogen-free medium. Under these conditions the pool size fell from 0.744 to $0.583 \mathrm{~m}$-moles $/ \mathrm{g}$. dry wt while the arginine content fell from 0.12 to $0.03 \mathrm{~m}$-moles/g. dry wt. This disproportionate decrease in arginine concentration could be correlated with a derepression of arginase in the absence of nitrogen-containing compounds in the medium. These results show that arginine in particular appears to function as a reserve of nitrogen in this organism and is mobilized in the absence of metabolizable nitrogen in the medium. Polakis et al. (I965) showed that the NADP-linked GDH of $S$. carlsbergensis was present in highest concentrations in cells grown in synthetic media, the enzyme content being greater in early log phase cells, when glucose remained in the medium, than at later stages of growth when this glucose had been utilized. These authors attributed this change to a decreased rate of growth and protein synthesis in the later stages of batch-cultivation. In the present experiments the rates of growth and protein synthesis were constant throughout and it seems most likely that GDH synthesis was controlled by the $\mathrm{NH}_{4}^{+}$concentration of the medium and the concentration of intracellular amino acids.

This work was supported in part by grant B/SR/5780 from the Science Research Council. We are grateful to the Brewers Society for a research studentship to Mr B. Johnson. We thank Mr A. Bradley and Mrs C. Jones for technical assistance.

\section{REFERENCES}

BABIJ, T., Moss, F. J. \& RaLPH, B. J. (I969). Effects of oxygen and glucose levels on lipid composition of the yeast Candida utilis grown in continuous culture. Biotechnology and Bioengineering Ir, 593.

BARTLEY, W. (1964). In Metabolism and Physiological Significance of Lipids, p. 378. Edited by R. M. C. Dawson \& D. N. Rhodes. London: Wiley.

BRown, C. M. (1970). The amino acid pools of yeasts. Journal of General Microbiology 58, iii.

BRown, C. M. \& Hough, J. S. (1965). Elongation of yeast cells in continuous culture. Nature, London 206, 676 .

Brown, C. M. \& Rose, A. H. (1969a). Effects of temperature on composition and cell volume of Candida utilis. Journal of Bacteriology 97, 261.

Brown, C. M. \& Rose, A. H. (1969 b). Fatty acid composition of Candida utilis as affected by growth temperature and dissolved oxygen tension. Journal of Bacteriology 99, 371. 
CRIDdle, R. S. \& Schatz, G. (1969). Promitochondria of anaerobically grown yeast. I. Isolation and biochemical properties. Biochemistry 8, 322.

Dawson, P. S. S. (1965). The intracellular amino acid pool of Candida utilis during growth in batch and continuous flow culture. Biochimica et biophysica acta III, 51 .

De Deken, R. H. (1966). The Crabtree effect, a regulatory system in yeast. Journal of General Microbiology 44, 149.

FAWCETT, J. K. \& SCOTT, J. E. (1960). A rapid and precise method for the determination of urea. Journal of Clinical Pathology 13, 156.

HARRIS, G. \& PARSONs, R. (1958). Nitrogenous constituents of brewing materials. XI. Nucleic acids of malt and their fate during brewing. Journal of the Institute of Brewing 64, 308.

Hоммes, F. A. (1966). Effect of glucose on the level of glycolytic enzymes in yeast. Archives of Biochemistry and Biophysics 114, 231.

KATES, M. (1964). Simplified procedures for hydrolysis or methanolysis of lipids. Journal of Lipid Research 5, 132.

Lowry, O. H., Rosebrough, M. R., FARr, A. L. \& Randall, R. J. (195I). Protein measurement with the Folin phenol reagent. Journal of Biological Chemistry 193, 265.

MARINETTI, G. V. (1962). Chromatographic separation, identification and analysis of phosphatides Journal of Lipid Research 3, I.

MidDleHoven, W. J. (1970). Induction and repression of arginase and ornithine transaminase in baker's yeast. Antonie van Leeuwenhook 36, I.

Paltauf, F. \& Schatz, G. (I969). Promitochondria of anaerobically grown yeast. II. Lipid composition. Biochemistry 8, 335.

Polakis, E. S., Bartley, W. \& Meek, G. A. (1965). Changes in the activities of respiratory enzymes during the aerobic growth of yeast on different carbon sources. Biochemical Journal 97, 298.

SLonimsKi, P. P. (I956). Adaptation respiratoire: développement de la système hemoproteique induit par l'oxygène. International Congress of Biochemistry 3, 242. 